\title{
Perlindungan Hukum Terhadap Investor Dalam Transaksi Jual Beli Efek Melalui Internet
}

Oleh

\author{
Rahmadiani Putri Nilasari*
}

\begin{abstract}
Abstrak
Pasar modal merupakan salah satu bagian dari pasar keuangan (financial market), di samping pasar uang (money market) yang sangat penting peranannya bagi pembangunan nasional pada umumnya, khususnya bagi pengembangan dunia usaha sebagai salah satu alternatif sumber pembiayaan eksternal oleh perusahaan. Di lain pihak dari sisi pemodal (investor), pasar modal sebagai salah satu sarana investasi dapat bermanfaat untuk menyalurkan dananya ke berbagai sektor produktif dalam rangka meningkatkan nilai tambah terhadap dana yang dimilikinya
\end{abstract}

Kata Kunci : pasar modal, investor, investasi

\section{Pendahuluan}

Untuk mengetahui makna perlindungan hukum tidak terlepas dari arti setiap kata yaitu "perlindungan" dan "hukum". Perlindungan berarti tempat berlindung. Sedangkan kata "hukum" mempunyai arti; 1) peraturan atau adat yang secara resmi dianggap mengikat, yang dikukuhkan oleh penguasa, pemerintah atau otoritas; 2) undang-undang, peraturan dan sebagainya untuk mengatur pergaulan hidup masyarakat; 3) patokan (kaidah, ketentuan) mengenai peristiwa (alam dan sebagainya) yang tertentu; 4) keputusan (pertimbangan) yang ditetapkan oleh hakim di (pengadilan) atau vonis ${ }^{1}$. Dengan demikian perlindungan *Fakultas Hukum Universitas Diponegoro,
rahmadiani_putri@yahoo.com
${ }^{1}$ Departemen Pendidikan dan Kebudayaan, Kamus
Besar Bahasa Indonesia, Balai Pustaka, Edisi II, Jakarta, hukum dapat diartikan sebagai melindungi masyarakat dari segala pelanggaran dan kejahatan yang diberikan oleh hukum yang berupa undang-undang maupun keputusan hakim yang sebagai yurisprudensi.

Pasar modal yang besar dan diperhitungkan ditentukan oleh nailai transaksi atau nilai kapitalisasi pasar dan kemampuannya untuk melindungi kepentingan para pihak terutama kepentingan investor karena investor tentunya mengharapkan keuntungan dengan melakukan investasi di pasar modal, tetapi karena setiap investasi mengandung risiko, ia harus menyadari bahwa tidak ada jaminan bahwa ia akan mendapatkan keuntungan.

Dalam melaksanakan investasi,

1997, Hlm. 360 
investor dihadapkan oleh adanya beberapa risiko berikut ini :

1. Risiko finansial, yaitu risiko yang diderita oleh pemodal sebagai akibat ketidakmampuan emiten memenuhi kewajiban pembayaran dividen/ bunga serta pokok investasi.

2. Risiko pasar, yaitu risiko akibat menurunnya harga pasar secara substansial, baik keseluruhan saham maupun saham tertentu akibat perubahan tingkat inflasi ekonomi, keuangan manajemen perusahaan negara, perubahan atau kebijaksanaan pemerintah.

3. Risiko psikologis, yaitu risiko bagi pemodal yang bertindak secara emosional dalam mengahdapi harga saham berdasarkan optimisme dan pesimisme dapat mengakibatkan kenaikan atau penurunan harga saham.

Sedangkan menurut R.L Hagin (1979), ada 5 jenis risiko yang dihadapi pemodal dalam menganalisis investasi, yaitu $:^{2}$

1. Interest rate risk; variasi dalam pendapatan yang disebabkan oleh adanya peubahan dalam tingkat suku bunga pasar. Jenis risiko ini biasanya muncul dalam investasi menghasilkan current income, yaitu bunga obligasi dan dividen saham. Nilai relatif dari jenis-jenis pendapatan tersebut akan bervariasi dengan pergerakan yang

${ }^{2}$ Adrian Sutedi, Segi-Segi Hukum Pasar Modal, (Bogor : Ghalia Utama, 2009), hlm 17 timbul dalam tingkat suku bunga pasar.

2. Liquidity risk, merupakan risiko yang berhubungan dengan menjadi uang kas.

3. Purchasing power risk, merupakan risiko yang berhubungan dengan adanya inflasi. Dengan adanya inflasi maka nilai secara riil akan lebih kecil dibandingkan dengan nilai nominalnya.

4. Business risk, merupakan risiko yang berhubungan dengan prospek bisnis dari (emiten) yang mengeluarkan saham. Keberhasilan perusahaan tergantung pada kemampuan manajemen untuk mengendalikan perusahaan dalam lingkungan yang terus berubah sehingga kalau misalnya perusahaan gagal dalam bisnisnya, pemodal akan ikut merasakan dampaknya.

5. Investment risk, merupakan risikoyang berhubungan dinamika permintaan dan penawaran sekuritas, fluktuasi harga sekuritas, dan harapannya terhadap prospek perusahaan.

\section{Perlindungan Hukum Menurut Undang- Undang No. 8 Tahun 1995 tentang Pasar Modal}

Undang-Undang No. 8 Tahun 1995 tentang Pasar Modal merupakan landasan hukum bagi keberadaan pasar modal di Indonesia telah memberikan jaminan kepastian hukum para pihak yang melakukan kegiatan di pasar modal serta perlindungan 
bagi investor. Konsekuensi perlindungan bagi investor adalah diterapkannya prinsip full disclosure, karena setiap keputusan investasi mengandung risiko maka emiten dan profesi penunjang di pasar modal harus bertanggungjawab terhadap keakuratan data dan kelengkapan informasi. Masalah yang berkaitan dengan kepentingan investor harus diperhatikan oleh pemerintah, termasuk mengenai perbaikan manajemen perusahaan yang telah go public.

Sebelum melakukan penawaran umum, sebagian besar perusahaan merupakan perusahaan keluarga (family company) yang saham dan manajemen perusahaannya dikuasai oleh anggota keluarga. Setelah melakukan penawaran umum, manajemen perusahaan seharusnya berubah dari tertutup menjadi terbuka, tetapi masih saja ada perusahaan yang belum merubah pola manajemennya. Hal ini akan mempengaruhi investor dalam hubungannya dengan :

1. Komposisi kepemilikan

Komposisi kepemilikan saham perusahaan yang telah go public umumnya masih belum seimbang antara founder dengan pemegang saham publik. 70\% saham masih dikuasai oleh founder dan pemegang saham publik hanya menguasai $30 \%$ saham. Komposisi kepemilikan saham tersebut menyebabkan bargaining position pemegang saham public lebih lemah dibandingkan dengan founder, karena itu pemegang saham publik memerlukan perlindungan melalui peraturan yang dibuat oleh pemerintah sehingga akan tercipta fairness dalam perolehan informasi dan securities transacsion lainnya.

2. Akses terhadapinformasi danfinancial resources

Posisi Dewan Komisaris dan Direksi perusahaan yang telah go public masih didominasi oleh founder yang otomatis mempunyai akses informasi keuangan yang lebih luas disbanding pemegang sahampublic. Ketimpanganiniberusaha diminimalisir dengan adanya peraturan yang mengharuskan perusahaan publik untuk mengumumkan atau melaporkan hal-hal penting yang terjadi pada perusahaan.

Dalam rangka mencapai tujuan menyelenggarakan perdagangan efek yang teratur, wajar, dan efisien Bursa efek wajib menyediakan sarana pendukung dan mengawasi kegiatan Anggota Bursa Efek. (Pasal 7 ayat (1) jo ayat (2) UU No. 8 Tahun 1995 tentang Pasar Modal).

Pasal 35 UU No. 8 Tahun 1995, Perusahaan efek atau penasihat investasi dilarang :

- Menggunakan pengaruh atau mengadakan tekanan yang bertentangan dengan kepentingan nasabah;

- Mengungkapkan nama atau kegiatan nasabah, kecuali diberi instruksi secara tertulis oleh nasabah atau diwajibkan menurut peraturan perundang-undangan yang berlaku; 
- Mengungkapkan secara tidak benar atau tidak mengungkapkan fakta yang material kepada nasabah mengenai kemampuan usaha atau keadaan keuangannya;

- Merekomendasikan kepada nasabah untuk membeli atau menjual efek tanpa memberitahukan adanya kepentingan perusahaan efek dan penasihat investasi dalam efek tersebut.

Pasal 46 Undang-Undang Pasar Modal, kustodian wajib memberikan ganti rugi kepada pemegang rekening atas setiap kerugian yang timbul akibat kesalahannya. Dan dalam pasal 60 ayat (1) UndangUndang Pasar Modal, pemegang rekening yang efeknya tercatat dalam penitipan kolektif berhak mengeluarkan suara dalam Rapat Umum Pemegang Efek. Pada pasal 78 ayat (1) ditegaskan bahwa setiap prospektus dilarang memuat keterangan yang tidak benar tentang fakta material atau tidak memuat keterangan yang benar tentang fakta material yang diperlukan agar prospektus tidak memberi gambaran yang menyesatkan. Dalam BAB XI Pasal 90-99 Undang-Undang No. 8 Tahun 1995 Tentang Pasar Modal sudah diatur mengenai penipuan, manipulasi pasar, dan perdagangan orang dalam. Dalam pasal 90 misalnya ditegaskan bahwa dalam kegiatan perdagangan efek, setiap pihak dilarang secara langsung atau tidak langsung :

a. Menipu atau mengelabui pihak lain dengan menggunakan sarana dan/ atau cara apapun;

b. Turut serta menipu atau mengelabui pihak lain;

c. Membuat pernyataan tidak benar mengenai fakta material atau tidak mengungkapkan fakta material agar pernyataan yang dibuat tidak menyesatkan mengenai keadaan yang terjadi pada saat pernyataan dibuat dengan maksud untuk menguntungkan atau menghindarkan kerugian untuk diri sendiri atau pihak lain atau dengan tujuan mempengaruhi pihak lain untuk membeli atau menjual efek.

Undang-Undang No. 8 Tahun 1995 tentang Pasar Modal telah dengan tegas mengatur perlindungan hukum terhadap investor yang melakukan transaksi di pasar modal. Begitupun dengan investor yang melakukan transaksi online meskipun belum ada pengaturan secara khusus namun Undang-Undang No. 8 Tahun 1995 tentang Pasar Modal tetap menjadi acuan apabila terjadi pelanggaran berupa penipuan, manipulasi pasar dan perdagangan orang dalam pada saat transaksi online dilaksanakan.

Dalam Bab XII tentang Pemeriksaan pasal 100 UUPM dikatakan bahwa Bapepam dapat melakukan pemeriksaan terhadap setiap pihak yang diduga melakukan atau terlibat dalam pelanggaran terhadap UU ini dan/ atau peraturan pelaksananya. BapepamLK tersebut dapat melakukan penyidikan terhadp tindak pidana di bidang pasar modal berdasarkan ketentuan dalam Kitab UndangUndang Hukum Acara Pidana (KUHAP). 
Dalam hasil penyidikan yang ditemukan oleh Bapepam-LK, BapepamLK dapat mengenakan sanksi administratif ataupun sanksi pidana terhadap pihak-pihak yang melakukan pelanggaran terhadap UUPM atau peraturan pelaksananya. Dalam menerapkan sanksi administratif, BapepamLK perlu memperhatikan aspek pembinaan terhadap pihak yang bersangkutan. Sanksi adminsitrasi dapat berupa peringatan tertulis, denda, pembatasan kegiatan usaha, pembekuan kegiatan usaha, pencabutan izin usaha, pembatalan persetujuan dan pembatalan pendaftaran. Dalam pasal 104 UUPM setiap pihak yang melanggar ketentuan penipuan, manipulasi pasar, dan insider trading diancam dengan pidana penjara paling lama 10 tahun dan denda paling banyak Rp. 15.000.000.000,-. Dengan demikian, dengan adanya ketentuanketentuan seperti yang dijelaskan di atas hal ini menunjukkan adanya perlindungan hukum terhadap investor. Investor dalam hal ini adalah investor secara keseluruhan baik itu investor yang melakukan transaksi efek secara manual maupuan yang melakukan transaksi melalui internet seperti yang saat ini lebih sering digunakan. Berbicara lebih lanjut mengenai perlindungan hukum terhadap investor yang melakukan transaksi melalui internet, memang saat ini belum ada aturan yang mengatur secara khusus, meskipun aturannya tengah dipersiapkan oleh Bapepam-LK.

\section{Perlindungan Hukum Menurut Undang- Undang No. 11 Tahun 2008 tentang Informasi dan Transaksi Elektronik}

Telah disebutkan dalam Pasal 5 ayat 1 UU No. 11 Tahun 2008 bahwa informasi elektronik dan/ atau dokumen elektronik dan/ atau hasil cetaknya merupakan alat bukti hukum yang sah. Dan ditegaskan kembali dalam pasal 5 ayat 2 UU No. 11 Tahun 2008 bahwa informasi elektronik dan/atau dokumen elektronik dan/ atau hasil cetaknya merupakan perluasan dari alat bukti yang sah sesuai dengan Hukum Acara yang berlaku di Indonesia.

Di dalam pasal 9 pun telah disebutkan salah satu kewajiban pelaku usaha yang menawarkan produk melalui Sistem Elektronik harus menyediakan informasi yang lengkap dan benar berkaitan dengan syarat kontrak, produsen, dan produk yang ditawarkan. Mengenai asas itikat baik juga ditegaskan di dalam pasal 17 ayat (2) yang berbunyi :
"Para pihak yang melakukan transaksi elektronik sebagaimana dimaksud pada ayat (1) wajib beritikat baik dalam melakukan interaksi dan/atau pertukaran informasi elektronik dan/ atau dokumen elektronik selama transaksi berlangsung."

Mengenai perbuatan-perbuatan yang dilarang telah diatur dalam BAB VII UU No. 11 Tahun 2008, salah satunya dalam pasal 30 ayat (2) setiap orang dengan sengaja dan tanpa hak atau melawan hukum mengakses komputer dan/ atau sistem elektronik dengan cara apa pun dengan tujuan untuk 
memperoleh Informasi Elektronik dan/ atau Dokumen Elektronik.

\section{Perlindungan Hukum Menurut Undang- Undang No. 8 Tahun 1999 tentang Perlindungan Konsumen}

Salah satu hak konsumen yang terdapat di dalam pasal 4 UU No. 8 Tahun 1999 adalah konsumen berhak atas informasi yang benar, jelas, dan jujur mengenai kondisi dan jaminan barang dan/ atau jasa, berhak untuk didengar pendapat dan keluhannya atas barang/ jasa yang digunakan dan berhak untuk mendapatkan advokasi, perlindungan, dan upaya penyelesaian sengketa perlindungan konsumen secara patut.

Mengenai adanya ketentuan pencantuman klausula baku pun sudah diatur dalam BAB V UU No. 8 Tahun 1999, salah satunya adalah pelaku usaha dalam menawarkan barang dan/ atau jasa yang ditujukan untuk diperdagangkan dilarang membuat atau mencantumkan klausula baku pada setiap dokumen dan/ atau perjanjian apabila menyatakan pengalihan tanggungjawab pelaku usaha.

\section{Perlindungan Hukum Menurut} Peraturan Badan Pengawas Pasar Modal (BAPEPAM-LK)

Perlindungan terhadap investor lebih banyak dilakukan oleh Bapepam. Sesuai dengan pasal 3 ayat (1) Undang-Undang No. 8 Tahun 1995, Bapepam mempunyai tiga fungsi utama,

"Pembinaan, pengaturan dan pengawasan sehari-hari kegiatan Pasar Modal dilakukan oleh Badan Pengawas Pasar Modal yang selanjutnya disebut Bapepam."

Dengan demikian terlihat bahwa di samping ketiga tugas pokok, Bapepam juga mempunyai tugas lainnya yang cukup luas. Dalam pelaksanaan tugas pengaturan, Bapepam telah berfungsi menjalankan fungsi "Rules Making" yakni membuat aturan-aturan yang berlaku di bidang pasar modal. Hal ini dijalankan dengan membuat berbagai aturan yang berlaku. Di bidang pengawasan, Bapepam tidak hanya menjalankan fungsi kontrol melainkan juga fungsi investigasi dan adjudicatory, bahkan dalam hal-hal tertentu telah berfungsi sebagai lembaga resmi peradilan (Quasi Judicial Power) artinya Bapepam tidak hanya bertugas dalam melakukan pemeriksaan suatu tindakan yang diduga telah melanggar hukum, namun juga dalam batas tertentu dapat menjatuhkan sanksi tertentu seperti sanksi administratif sekaligus mengeksekusi putusan tersebut.

Online trading merupakan sebuah aplikasi Teknologi Informasi dalam mekanisme perdagangan saham dan sampai saat ini belum ada peraturan khusus yang dikeluarkan oleh Bapepam untuk pengaturan aplikasi teknologi tersebut. Namun saat ini Bapepam selaku otoritas tertinggi di Pasar Modal telah menyetujui semua peraturan tentang aplikasi teknologi dalam mekanisme perdagangan saham yang dikeluarkan oleh Bursa Efek.

Telah dikatakan sebelumnya bahwa 
kepentingan publik atau investor harus dilindungi.Perlindunganhukumbagiinvestor memang penting, tetapi bukan segalanya. Perangkat hukum yang bagaimanapun, selalu mempunyai ruang untuk diterobos dan tidak ada yang sempurna. Karena itu, satu hal yang tidak kalah pentingnya adalah upaya-upaya mengigatkan emiten akan tanggung jawab moralnya. Tanggung jawab moral ini antara lain, seperti penggunaan dana go publik sesuai dengan maksud yang dinyatakan sebelumnya, pemberian informasi yang benar dan tidak distorsi, kejujuran pelaksanaan perusahaan dan sebagainya.

Kemudian sebagai perlindungan pada tahap berikut diberikan dan diantisipasi oleh peraturan-peraturan yang dikeluarkan oleh Bapepam sebagai instansi yang mempunyai wewenang untuk mengawasi pasar modal Indonesia. Secara tidak langsung, sebagian dari sistem perlindungan hukum bagi investor itu berada di tangan Bapepam. Untuk menjamin adanya perlindungan yang dimaksud, Bapepam telah mengambil langkah-langkah sebagai berikut :

1. Menerbitkan peraturan tentang preemtive right, yaitu peraturan tentang hak memesan efek terlebih dahulu.

2. Membuat peraturan tentang transaksi yang mengandung benturan kepentingan.

3. Meningkatkan keterbukaan emiten.

4. Menciptakan peraturan-peraturan lain yang mengarah kepada pembeli perlindungan kepada publik.
Demikian pula agar penyampaian informasi lebih merata, tepat waktu dan akurat Bapepam mengambil langkahlangkah penting dalam meningkatkan penyebaran informasi dengan membentuk public information service office (PISO). Dengan adanya PISO, maka investor dengan mudah memperoleh informasi yang dibutuhkan tentang perusahaan-perusahaan yang go public. Bapepam juga mensyaratkan kepada emiten serta profesi penunjang pasar modal lainnya untuk lebih terbuka dalam pemberian informasi.

Keputusan Ketua Badan Pengawas Pasar Modal Nomor KEP- 42/PM/1997 (Peraturan III.A.10) tentang Transaksi Efek, KEP-46/PM/2004 (Peraturan III.B.6) tentang Penjaminan Penyelesaian Transaksi Bursa adalah beberapa keputusan Bapepam yang mengatur mengenai ketentuan transaksi efek. Dalam Peraturan Nomor III.A.10 tentang Transaksi Efek, disebutkan bahwa bursa efek dilarang membuat peraturan yang melarang atau menghalangi Perusahaan efek, emiten, Biro Administrasi Efek, atau pihak lain salah satunya untuk mengalihkan efek menjadi atas nama perusahaan efek atau Lembaga Kliring dan Penjaminan untuk digunakan sebagai jaminan.

\section{Pelindungan Hukum Menurut Peraturan} Bursa Efek

Bursa efek adalah pihak yang menyelenggarakan dan menyediakan sistem dan atau sarana untuk mempertemukan penawaran jual dan beli efek pihak-pihak lain dengan tujuan memperdagangkan efek di antara mereka. Bursa efek didirikan dengan 
tujuan menyelenggarakan perdagangan efek yang teratur, wajar dan efisien, dengan berkonsentrasi pada upaya : ${ }^{3}$

1. Meningkatkan likuiditas dan efisiensi biaya. Untuk itu bursa efek perlu melakukan peninjauan, perbaikan, dan penyempurnaan terhadap peraturan bursa agar tetap sesuai dengan standar internasional.

2. Meningkatkan keamanan transaksi bursa. Keamanan transaksi di bursa efek perlu ditingkatkan dengan melakukan kegiatan pemantauan secara kontinu agar risiko investasi berkurang, mengharuskan anggota bursa mengasuransikan dana nasabah, mengembangkan jaringan teknologi, menyelesaikan secara tuntas, cepat dan adil kasus-kasus yang terjadi di bursa.

3. Meningkatkan jenis dan kualitas pelayanan bursa. Bursa efek dengan status hukumnya sekarang ini, diharapkan mampu memantapkan mekanisme sistem perdagangan pasar ekuitas dan obligasi.

Dengan demikian terlihat bahwa Bursa Efek juga berfungsi melaksanakan pengawasan terhadap Anggota Bursa Efek. Bursa Efek juga mempunyai fungsi sebagai "Self Regulatory Body, yakni berkewenangan mengeluarkan peraturan yang berlaku untuk anggotanya. Dalam menjalankan pengawasan pasar, bursa efek dapat menempuh dua cara, yaitu $:^{4}$

\footnotetext{
3 M Irsan Nasarudin dkk, Aspek Hukum Pasar Modal Indonesia, (Jakarta: Kencana, 2008)

${ }^{4}$ Ibid, hlm 125
}

1. Melakukan pengawasan sebagai kontrolinternalbagisistempembukuan atau keuangan anggota bursa.

2. Melakukan pendeteksian dini (early warning) dalam memonitor transaksi setiap saat di lantai bursa.

Sejauh ini belum ada peraturan dan panduan online trading di Indonesia. Namun seiring dengan semakin menjamurnya layanan online trading yang diberikan oleh beberapa perusahaan sekuritas, BEI sedang menyusun panduan online trading ini. Demi melindungi kepentingan nasabah, pada panduan regulasi tersebut akan ada pihak ketiga untuk melakukan audit atas kecukupan online trading, infrastruktur, mekanisme perdagangan, trouble shooting dan help desk. Panduan regulasi diperlukan untuk melindungi investor dan angora bursa sehingga masing-masing pihak mengetahui hak dan kewajibannya dalam online trading. 5

Menurut pasal 9 ayat (1) jo ayat (2) Undang-Undang No. 8 Tahun 1995 Bursa efek wajib menetapkan peraturan mengenai perdagangan dan tata cara peralihan efek sehubungan dengan transaksi bursa.

\section{Perlindungan Hukum Yang Diberikan Oleh Lembaga Kliring dan Penjaminan (LKP)}

Pembentukan Lembaga Kliring dan Penjaminan (LKP) diatur berdasarkan pasal 13-17 UU No. 8 Tahun 1995 tentang Pasar Modal, serta pasal 15-22 PP 45/1995tentang Penyelenggaraan Kegiatan di Bidang Pasar

${ }^{5}$ Endang Purwaningsih, Hukum Bisnis, (Bogor: Ghalia Utama) 
Modal. Tujuan Pendirian Lembaga ini adalah untuk meneyediakan jasa kliring dan penjaminan penyelesaian transaksi bursa yang teratur, wajar, dan efisien. ${ }^{6}$

Di dalama peraturan II-1 mengenai Jasa Kliring dan Penjaminan Penyelesaian Transaksi Bursa Tanpa Warkat, Peraturan II-5 tentang Kliring Transaksi Bursa Tanpa Warkat dan Peraturan II-7 tentang Kegagalan Pemenuhan Hak dan Kewajiban Anggota Kliring Secara Pemindahbukuan telah diatur mengenai transaksi efek tanpa warkat.

\section{Perlindungan Hukum Yang Diberikan Oleh Lembaga Penyimpanan dan Penyelesaian (LPP)}

Lembaga Penyimpanan dan Penyelesaian adalah pihak yang menyelenggarakan kegiatan custodian sentral bagi bank custodian, perusahan efek, dan pihak lain. Kustodian adalah pihak yang memberikan jasa penitipan efek dan harta lain yang berkaitan dengan efek serta jasa lain- termasuk menerima dividen, bunga, dan hak-hak lain, menyelesaikan transaksi efek, dan mewakili pemegang rekening yang menjadi nasabahnya. Saat ini pihak yang bertugas sebagai Lembaga Penyimpanan dan Penyelesaian adalah PT Kustodian Sentral Efek Indonesia (KSEI). Tugas KSEI adalah wajib menetapkan peraturan mengenai jasa custodian sentral dan jasa penyelesaian transaksi efek, termasuk ketentuan mengenai biaya pemakaian jasa tersebut. KSEI juga wajib

${ }^{6}$ Iswi Hariyani dan R. Serfianto, Buku Pintar Hukum Bisnis Pasar Modal, (Jakarta: Visi Media, 2010), hlm 41 mengamankan proses pemindahbukuan efek serta menyelesaikan penyerahan efek (settlement).

PT KSEI didirikan di Jakarta, 23 Desember 1997 dan memperoleh izin operasional pada 11 November 1998. Dalam kelembagaan pasar modal Indonesia, KSEI merupakan salah satu Self Regulatory Organization (SRO), selain bursa efek dan Lembaga Kliring dan Penjaminan.

Mekanisme pendirian LPP sama dengan pendirian lembaga kliring dan penjaminan (LKP), yaitu berdasarkan pasal 13 sampai pasal 17 UU No. 8 tahun 1995 tentang pasar modal, serta pasal 15 hingga pasal 22 PP No. 45/ 1995 tentang Penyelenggaran Kegiatan di Bidang Pasar Modal. Pendirian LPP juga diatur sebagai Keputusan Ketua Bapepam No. Kep-12/PM/1996 tentang Perizinan Lembaga Penyimpanan dan Penyelesaian.

KSEI melakukan fungsi sebagai kustodian sentral yang aman dalam rangka penitipan efek dengan kewajiban memenuhi persyaratan teknis tersebut. Oleh karena itu jasa custodian yang ada di KSEI harus lengkap seperti berikut : ${ }^{7}$

1. Bidang penatausahaan rekening efek untuk menyimpan kas dan efek.

2. Penerimaan dan distribusi dividen, bunga, pokok pinjaman, saham bonus dan hak-hak lainnya.

3. Pemindahan efek, keluar dan masuknya pentipan kolektif.

4. Pemindahan efek dari suatu rekening ke rekening lainnya berdasarkan

7 Ibid., hlm 54 
instruksi atau tanpa pembayaran.

5. Penjualan hak atau pecahannya dan pelaksanaan hak yang timbul dari kepemilikan efek.

6. Pembayaranpajakmaupunpenerimaan restitusi pajak.

Di samping itu KSEI juga dapat memberikan jasa-jasa lain sebagai berikut :

1. Penyampaian laporan mengenai jasajasa yang perlu diketahui pemegang efek.

2. Pelaksanaan pemberian kuasa untuk hadir dan memberikan suara dalam RUPS.

3. Pemberian informasi kepada emiten mengenai kepemilikan efek dalam.

4. Penitipan kolektif dan pelaporan kegiatan rekening efek.

Peluncuran fasilitas investor area dilakukan oleh PT Kustodian Sentral Efek Indonesia pada tanggal 17 Juni 2009. Sehari kemudian investor area ini resmi beroperasi setelah melewati berbagai persiapan teknis dan sosialisasi serta edukasi bagi para penggunanya. Fasilitas Investor Area yang terdapat dalam sistem operasional KSEI ini merupakan salah satu bentuk komitmen KSEI untuk menciptakan pasar yang semakin likuid, wajar, teratur dan transparan. Untuk implementasi tersebut, KSEI telah melakukan persiapan dari sisi sistem, operasional bisnis dan teknis serta sosialisasi. Agar fasilitas ini dapat digunakan dengan aman, telah dilakukan pula pemeriksaan yang mendalam dan menyeluruh oleh konsultan independent dengan hasil akhir bahwa fasilitas ini dinyatakan cukup aman untuk dioperasikan. Segala risiko telah ditekan hingga ke titik yang rendah. Fasilitas Investor Area merupakan sarana bagi investor sebagai nasabah Pemegang Rekening KSEI untuk memperoleh informasi terkait Efek miliknya, sehingga mereka bisa mengetahui dan memonitor posisi atau mutasi Efek miliknya dalam Sub Rekening Efek yang disimpan di KSEI. Sesuai surat Bapepam-LK No.: S-4882/ BL/2009 tanggal 8 Juni 2009, Pemegang Rekening wajib memenuhi permintaan investor yang menjadi nasabahnya untuk memperoleh akses atas fasilitas Investor Area ini. ${ }^{8}$

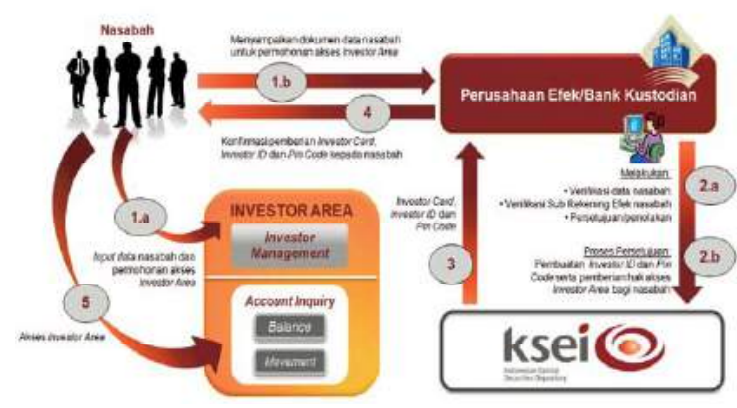

Fasilitas Investor Area yang dapat diakses melalui website KSEI ini diharapkan mampu memberikan perlindungan dan transparansi atas portofolio investasi milik investor dan meningkatkan kepercayaan investor untuk berinvestasi di pasar modal Indonesia. Melalui fasilitas ini, investor dapat mengakses secara real time data kepemilikan posisiEfek dalam SubRekening Efek serta mutasi pergerakan Efek miliknya yang tercatat di sistem operasional KSEI yang bernama C-BEST hingga 30 hari ke belakang.

${ }^{8}$ Fokuss (Forum Kustodian SentraL Efek Indonesia), edisi 03 Tahun 2009 


\section{Kesimpulan}

1. Investasi online stock trading saat ini mulai "digemari" oleh kebanyakan masyarakat Indonesia yang kebanyakan adalah investor ritel. Namun perkembangan tersebut tidak selamanya baik. Perkembangan pasar modal yang terlalu cepat akan menciptakan bubble ekonomi di kemudian hari, jika tidak diimbangi oleh peningkatan ekonomi pada sektor riil.

2. Bapepam-LK selaku pengawas kegiatan di pasar modal seharusnya dapat mengatur secara ketat sistem online stock trading. Misalnya dengan menetapkan saldo minimum yang layak untuk dapat berinvestasi saham, sehingga investor ritel yang berinvestasi di pasar modal bukan sembarang investor. Selain itu, sistem margin yang difasilitasi oleh sekuritas juga harus diregulasi kembali.

\section{DAFTAR BACAAN}

Departemen Pendidikan dan Kebudayaan, Kamus Besar Bahasa Indonesia, Balai Pustaka, Edisi II, Jakarta, 1997

Adrian Sutedi, Segi-Segi Hukum Pasar Modal, (Bogor : Ghalia Utama, 2009)

M Irsan Nasarudin dkk, Aspek Hukum Pasar Modal Indonesia, (Jakarta: Kencana, 2008)

Endang Purwaningsih, Hukum Bisnis, (Bogor: Ghalia Utama)

Iswi Hariyani dan R. Serfianto, Buku Pintar Hukum Bisnis Pasar Modal, (Jakarta: Visi Media, 2010),

Fokuss (Forum Kustodian SentraL Efek Indonesia), edisi 03 Tahun 2009 
286 Yuridika: Volume 26 No 3, September-Desember 2011 